\title{
Redox Chemistry in the Reaction of Oxovanadium(v) with Thiolate-Containing Ligands: the Isolation and Characterization of Non-Oxo Vanadium(IV) Complexes Containing Disulfide and Thioether Groups
}

\author{
Hua-Fen Hsu, ${ }^{*[a]}$ Chia-Ling Su, ${ }^{[a]}$ Neeruganti O. Gopal, ${ }^{[b]}$ Chi-Chin $\mathrm{Wu},{ }^{[a]}$ \\ Wei-Cheng Chu, ${ }^{[\text {a] }}$ Yi-Fang Tsai, ${ }^{[\text {a] }}$ Ya-Ho Chang, ${ }^{[a]}$ Yi-Hung Liu, ${ }^{[\mathrm{le}}$ Ting-Shen Kuo, ${ }^{[\mathrm{d}]}$ and \\ Shyue-Chu Ke*[b]
}

Keywords: Vanadium / S ligands / Bioinorganic chemistry / EPR spectroscopy

The reactions of $\mathrm{V}^{\mathrm{V}} \mathrm{O}(\mathrm{O}-\mathrm{Pr})_{3}$ with $\left[\mathrm{PS}^{\prime}\right] \mathrm{H}_{3}$ and $[\mathrm{PS} 3] \mathrm{H}_{3}$ $\left\{\left[\mathrm{PS}^{\prime}\right] \mathrm{H}_{3}=\mathrm{P}\left(\mathrm{C}_{6} \mathrm{H}_{3}-5-\mathrm{Me}-2-\mathrm{SH}\right)_{3},[\mathrm{PS} 3] \mathrm{H}_{3}=\mathrm{P}\left(\mathrm{C}_{6} \mathrm{H}_{4}-2-\mathrm{SH}\right)_{3}\right\}$ led to the formation of $\left[\mathrm{V}^{\mathrm{IV}}(\mathrm{L})\right]\left[\mathrm{L}=\mathrm{P} 2 \mathrm{~S} 44^{\prime}\right.$ (1a), P2S4 (1) $\left.)\right]$, where L was formed by the oxidative coupling of two PS3' or PS3 ligands by a disulfide bond. When the reaction of $\mathrm{V}^{\mathrm{V}} \mathrm{O}(\mathrm{O}-\mathrm{iPr})_{3}$ with $\left[\mathrm{PS}^{\prime}\right] \mathrm{H}_{3}$ was conducted in the presence of methoxide followed by the addition of a cation, $\left[\mathrm{V}^{\mathrm{IV}}\left(\mathrm{PS}^{\prime}\right)\right.$ $\left.\left(\mathrm{PS}^{\mathrm{Me}} \mathrm{Se}^{\mathrm{M}}\right)\right] \mathrm{X}\left[\mathrm{X}=\mathrm{N}\left(\mathrm{C}_{2} \mathrm{H}_{5}\right)_{4}(\mathbf{2 a}), \mathrm{N}\left(\mathrm{C}_{2} \mathrm{H}_{5}\right)_{3}\left(\mathrm{CH}_{2} \mathrm{Ph}\right)(\mathbf{2 b})\right]$ was isolated, where $\mathrm{PS}_{2} \mathrm{~S}^{\mathrm{Me} \prime}$ is a bis(benzenethiolato)phenylmethylthioetherphosphane ligand generated from the meth- ylation of one thiolate group in PS3'. The structures of complexes $\mathbf{1} \mathbf{a}, \mathbf{b}$ and $\mathbf{2 a} \mathbf{a} \mathbf{b}$, determined by X-ray crystallography, contain six- and seven-coordinate non-oxo vanadium(IV) centers, respectively, with an octahedral geometry for $\mathbf{1} \mathbf{a}, \mathbf{b}$ and a pentagonal-bipyramidal geometry for $\mathbf{2} \mathbf{a}, \mathbf{b}$. The electronic, magnetic, and electrochemical properties of these complexes were determined by UV/Vis and EPR spectroscopy, SQUID measurements, and cyclic voltammetry. (® Wiley-VCH Verlag GmbH \& Co. KGaA, 69451 Weinheim, Germany, 2006)

\section{Introduction}

Vanadium has been shown to have an important role in biological systems and therefore its complexes are worth investigation. ${ }^{[1]}$ In particular, the interactions of high-valent vanadium species with sulfur-containing bioligands, such as cysteine and glutathione, are essential subjects in various biological and medical topics. ${ }^{[1 \mathrm{a}, 2]}$ Vanadate interacts with the Cys residue in the catalytic site of the protein-tyrosine phosphatase (PTP), inhibiting the activity of the enzyme that might be associated with the insulin-mimetic behavior of vanadium compounds. ${ }^{[3]}$ Some ascidians sequester $\mathrm{V}^{\mathrm{V}}$ species from seawater and reduce it to $\mathrm{V}^{\mathrm{III}}$ which is accumulated in high concentration in vacuoles of the blood cells. ${ }^{[4]}$ The mechanism for this redox conversion is still unknown. In addition to tunichrome and NADPH, glutathione and cysteine might be candidates to act as reductants in the cell. ${ }^{[5]}$ A natural vanadium(IV) complex, amavadin, was iso-

[a] Department of Chemistry, National Cheng Kung University, Tainan 701, Taiwan

Fax: +886-6-2740552

E-mail: konopka@mail.ncku.edu.tw

[b] Department of Physics, National Dong Hua University, Hualien, Taiwan

[c] Department of Chemistry, National Taiwan University, Taipei 117, Taiwan

[d] Department of Chemistry, National Taiwan Normal University, Taipei 116, Taiwan

$\square$ Supporting information for this article is available on the WWW under http://www.eurjic.org or from the author. lated from Amanita mushrooms. ${ }^{[6]}$ Even though the structure of this complex is known, its function is still not well understood. ${ }^{[7]}$ It has been suspected that amavadin might be involved in the defensive system of the mushrooms through the specific oxidation of some thiols to disulfide. ${ }^{[8]}$ The toxicity of vanadium in biological systems is not well understood, however, it has been shown that the injection of vanadate in mice decreased the cellular level of glutathione, an essential antioxidant in the cell. ${ }^{[9]}$ Vanadium complexes with S-donor ligands have been shown to have insulin-mimetic antidiabetic activity. ${ }^{[10]}$

From this information, efforts have been made to understand the fundamental chemistry of high-valent vanadium complexes with thiolate ligands that have similar functional groups to those in cysteine and glutathione. ${ }^{[11]}$ Among those studies, the interaction of $\mathrm{VO}^{3+}$ species with thiolatecontaining ligands has not been intensively investigated. ${ }^{[11 \mathrm{~b}, 11 \mathrm{~d}]}$ Therefore, in this paper we focus on the chemistry of $\mathrm{VO}^{3+}$ reacting with the tris(benzenethiolato)phosphane ligands, $[\mathrm{PS} 3] \mathrm{H}_{3}$ and $\left[\mathrm{PS}^{\prime}\right] \mathrm{H}_{3}$. The reactions led to the reduction of vanadium(v) to vanadium(IV) with the formation of the two new types of ligands, $\mathrm{L}(\mathrm{L}=\mathrm{P} 2 \mathrm{~S} 4$ and P2S4') and PS2S ${ }^{\mathrm{Me}}$ (see Scheme 1). The former was created by the oxidative coupling of two PS3 ligands by way of a disulfide linkage, and the latter resulted from the methylation of one thiolate group in the PS3' ligand. We verified this chemistry by isolating the reaction products, $\left[\mathrm{V}^{\mathrm{IV}}(\mathrm{L})\right]$ $\left[\mathrm{L}=\mathrm{P} 2 \mathrm{~S} 4^{\prime}(\mathbf{1 a}), \mathrm{P} 2 \mathrm{~S} 4(\mathbf{1 b})\right]$ and $\left[\mathrm{V}^{\mathrm{IV}}\left(\mathrm{PS}^{\prime}\right)\left(\mathrm{PS}_{2} \mathrm{~S}^{\mathrm{Me}}\right)\right] \mathrm{X}[\mathrm{X}$ 
$\left.=\mathrm{N}\left(\mathrm{C}_{2} \mathrm{H}_{5}\right)_{4}(\mathbf{2 a}), \mathrm{N}\left(\mathrm{C}_{2} \mathrm{H}_{5}\right)_{3}\left(\mathrm{CH}_{2} \mathrm{Ph}\right)(\mathbf{2} \mathbf{b})\right]$ (Scheme 2). Notably, 1a,b and 2a,b belong to a limited set of non-oxo (or "bare") vanadium complexes. ${ }^{[12]}$ The interest in non-oxo vanadium species stems from amavadin and vanadium nitrogenase that contain an eight-coordinate non-oxo vanadium center and a $\left[\mathrm{V}(\mu-\mathrm{S})_{3}(\mathrm{His})\right.$ (homocitrate)] site, respectively. Herein, we describe the syntheses, structures, spectroscopy, and magnetic properties of $\mathbf{1 a}, \mathbf{b}$ and $\mathbf{2} \mathbf{a}, \mathbf{b}$, as well as the significance of the chemistry provided in this work.
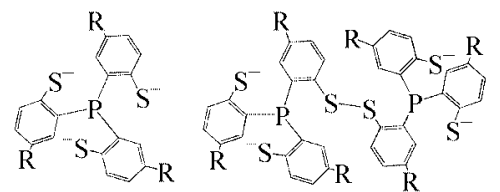

$\mathrm{R}=\mathrm{H}: \mathrm{PS} 3$

$\mathrm{R}=\mathrm{CH}_{3}: \mathrm{PS} 3$

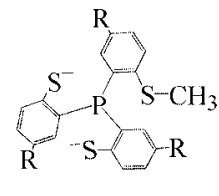

$\mathrm{R}=\mathrm{H}: \mathrm{PS} 2 \mathrm{~S}^{\mathrm{Me}}$

$\mathrm{R}=\mathrm{CH}_{3}: \operatorname{PS} 2 \mathrm{~S}^{\mathrm{Me}}$
Scheme 1

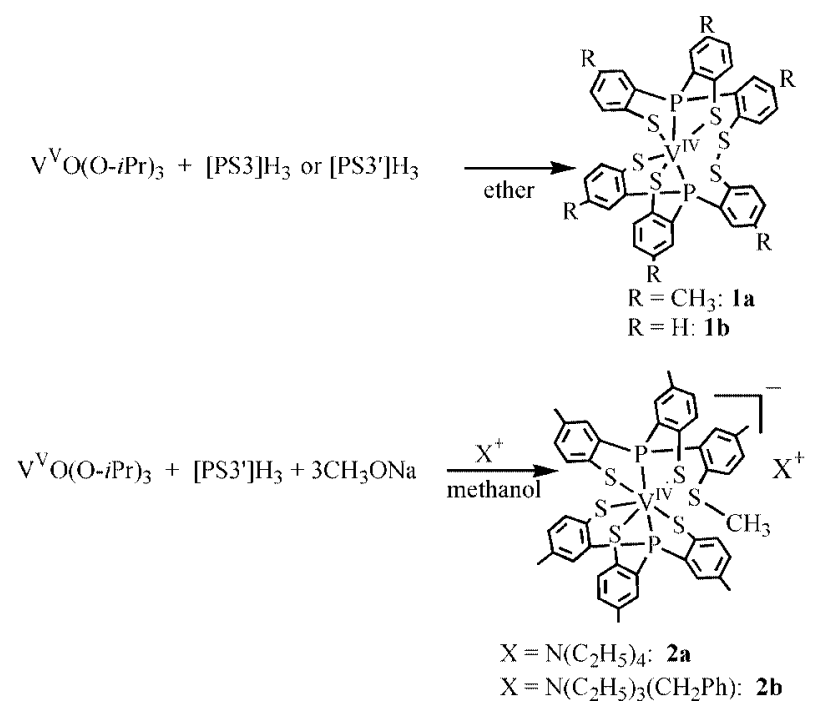

Scheme 2.

\section{Results and Discussion}

\section{Syntheses and X-ray Structures}

The reaction of 1 equiv. $\left[\mathrm{PS}^{\prime}\right] \mathrm{H}_{3}$ in ether with 1 equiv. $\mathrm{V}^{\mathrm{V}} \mathrm{O}(\mathrm{O}-i \mathrm{Pr})_{3}$ in $i \mathrm{PrOH}$ generated a purple solid that was recrystallized from dichloromethane/hexane to give the crystalline form of $\left[\mathrm{V}^{\mathrm{IV}}\left(\mathrm{P} 2 \mathrm{~S} 4^{\prime}\right)\right](\mathbf{1 a})$. The synthetic procedure of $\left[\mathrm{V}^{\mathrm{IV}}(\mathrm{P} 2 \mathrm{~S} 4)\right](\mathbf{1 b})$ was similar to that of 1a except $[\mathrm{PS} 3] \mathrm{H}_{3}$ was used and the compound was recrystallized from benzene/ether. When $\mathrm{V}^{\mathrm{V}} \mathrm{O}(\mathrm{O}-i \mathrm{Pr})_{3}$ in $i \mathrm{PrOH}$ was added to equimolar amounts of $\left[\mathrm{PS}^{\prime}\right] \mathrm{H}_{3}$ in methanol with the presence of sodium methoxide, a transient brown solution was produced which gradually changed to a purple color in one hour. After addition of the counterion, X, the purple crystalline solid of $\left[\mathrm{V}^{\mathrm{IV}}\left(\mathrm{PS}^{\prime}\right)\left(\mathrm{PS}^{2} \mathrm{~S}^{\mathrm{Me}}\right)\right] \mathrm{X}[\mathrm{X}=$ $\mathrm{N}\left(\mathrm{C}_{2} \mathrm{H}_{5}\right)_{4}$ (2a), $\mathrm{N}\left(\mathrm{C}_{2} \mathrm{H}_{5}\right)_{3}\left(\mathrm{CH}_{2} \mathrm{Ph}\right)$ (2b)] precipitated from the solution by the next day. When the reactions were per- formed with $\mathrm{V}^{\mathrm{V}} \mathrm{O}(\mathrm{O}-i \mathrm{Pr})_{3}$ and the ligands in a molar ratio of 1:2, there were no appreciable gains in the yields of compounds 1a,b and $\mathbf{2 a}, \mathbf{b}$. The solid forms of these complexes were stable in the air, however, the solution forms decomposed within minutes of exposure to the air.

The structure of 1a was obtained by X-ray crystallography, but it was poorly refined as a result of the weak intensity of the data. Compound $\mathbf{1 b}$ afforded X-ray crystallographic data of better quality and its ORTEP diagram is shown in Figure 1. It consists of a $\mathrm{V}^{\mathrm{IV}}$ ion coordinated to a hexadentate ligand, P2S4, with a nine-membered chelate ring containing a $\mathrm{S}-\mathrm{S}$ bond. The vanadium(IV) center adopts a distorted octahedral geometry by binding to two phosphane atoms and four thiolate groups of P2S4, with the two $\mathrm{P}$ donor atoms in cis positions. The generation of $\mathrm{P} 2 \mathrm{~S} 4$ by the reaction was a consequence of the oxidative coupling of two PS3 ligands by formation of a disulfide linkage. Similar chemistry was also found in the reaction of $\mathrm{Os}^{\mathrm{II}}$ with the PS3 ligand, however, two disulfide linkages were formed. ${ }^{[13]}$ Redox chemistry of $\mathrm{V}^{\mathrm{V}} / \mathrm{V}^{\mathrm{IV}}$ coupled with $\mathrm{RS}^{-} / \mathrm{RSSR}$, as demonstrated by the isolation of $\mathbf{1 a}, \mathbf{b}$, is unprecedented, although the chemistry of $\mathrm{V}^{\mathrm{IV}} / \mathrm{V}^{\mathrm{III}}$ coupled with $\mathrm{RS}^{-} / \mathrm{RSSR}$ has been reported. ${ }^{[11 \mathrm{e}, 11 \mathrm{~g}]}$ To the best of our knowledge, hexadentate $\mathrm{P} 2 \mathrm{~S} 4$ and $\mathrm{P} 2 \mathrm{~S} 4$ ' ligands containing two phosphane and four thiolate donor atoms have not been presented in the literature. Selected bond lengths and angles of $\mathbf{1 b}$ are listed in Table 1 . The $\mathrm{V}-\mathrm{S}$ distances of 2.307-2.335 $\AA$ in $\mathbf{~} \mathbf{b}$ are in the range of those for reported $\mathrm{V}^{\mathrm{IV}}$-thiolate complexes. ${ }^{[11 \mathrm{a}, 11 \mathrm{~d}-11 \mathrm{~h}]}$ The $\mathrm{S}$ atoms of the disulfide linkage remain uncoordinated, and the $\mathrm{S}-\mathrm{S}$ distance of $2.055 \AA$ is similar to those in characterized disulfide-containing compounds. ${ }^{[11 \mathrm{~d}, 11 \mathrm{f}]}$

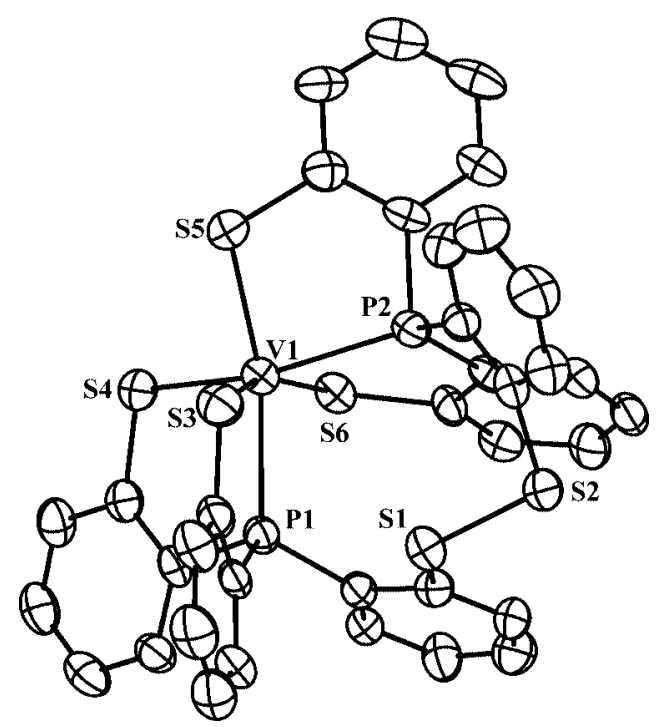

Figure 1. ORTEP diagram of $\mathbf{1 b}$ shown with $35 \%$ thermal ellipsoids. All hydrogen atoms are omitted for clarity.

The structures of $\mathbf{2 a}$ and $\mathbf{2 b}$ were determined by X-ray crystallography and their anions are very similar (see Figure S1 and Figure 2, respectively). However, 2b provides a better quality of X-ray crystallographic data and is discussed here. The anion of $\mathbf{2} \mathbf{b}$ consists of a seven-coordinate $\mathrm{V}^{\mathrm{IV}}$ 
Table 1. Selected bond lengths $[\AA]$ and angles $\left[{ }^{\circ}\right]$ for $\mathbf{1 b} \cdot 2 \mathrm{C}_{6} \mathrm{H}_{6}$.

\begin{tabular}{lclc}
\hline $\mathrm{V}(1)-\mathrm{S}(3)$ & $2.335(3)$ & $\mathrm{V}(1)-\mathrm{S}(4)$ & $2.307(2)$ \\
$\mathrm{V}(1)-\mathrm{S}(5)$ & $2.329(3)$ & $\mathrm{V}(1)-\mathrm{S}(6)$ & $2.325(2)$ \\
$\mathrm{S}(1)-\mathrm{S}(2)$ & $2.055(3)$ & $\mathrm{V}(1)-\mathrm{P}(1)$ & $2.442(2)$ \\
$\mathrm{V}(1)-\mathrm{P}(2)$ & $2.500(2)$ & & \\
$\mathrm{S}(4)-\mathrm{V}(1)-\mathrm{S}(3)$ & $107.45(9)$ & $\mathrm{S}(3)-\mathrm{V}(1)-\mathrm{P}(1)$ & $80.43(8)$ \\
$\mathrm{S}(4)-\mathrm{V}(1)-\mathrm{S}(6)$ & $84.73(9)$ & $\mathrm{S}(3)-\mathrm{V}(1)-\mathrm{P}(2)$ & $94.58(9)$ \\
$\mathrm{S}(4)-\mathrm{V}(1)-\mathrm{S}(5)$ & $90.18(9)$ & $\mathrm{S}(6)-\mathrm{V}(1)-\mathrm{S}(3)$ & $157.69(10)$ \\
$\mathrm{S}(4)-\mathrm{V}(1)-\mathrm{P}(1)$ & $84.31(8)$ & $\mathrm{S}(6)-\mathrm{V}(1)-\mathrm{S}(5)$ & $110.40(9)$ \\
$\mathrm{S}(4)-\mathrm{V}(1)-\mathrm{P}(2)$ & $156.88(9)$ & $\mathrm{S}(6)-\mathrm{V}(1)-\mathrm{P}(1)$ & $82.35(8)$ \\
$\mathrm{S}(5)-\mathrm{V}(1)-\mathrm{S}(3)$ & $88.65(10)$ & $\mathrm{S}(6)-\mathrm{V}(1)-\mathrm{P}(2)$ & $76.94(8)$ \\
$\mathrm{S}(5)-\mathrm{V}(1)-\mathrm{P}(1)$ & $165.64(9)$ & $\mathrm{P}(1)-\mathrm{V}(1)-\mathrm{P}(2)$ & $106.74(8)$ \\
$\mathrm{S}(5)-\mathrm{V}(1)-\mathrm{P}(2)$ & $83.25(8)$ & & \\
\hline
\end{tabular}

center by binding to PS3' and $\mathrm{PS}_{2} \mathrm{~S}^{\mathrm{Me}}$, where $\mathrm{PS}^{2} \mathrm{~S}^{\mathrm{Me}}$ ' is a bis(thiolato)thioetherphosphane ligand. Interestingly, during the reaction a thiolate group in the PS3' ligand was methylated to yield the PS2S ${ }^{\mathrm{Me}}$ ligand. The $\mathrm{S}(2)-\mathrm{C}(10)$ distance of 1.763(5) $\AA$ is close to those found in methylphenyl thioether-containing compounds, ${ }^{[14]}$ but is different from the reported $\mathrm{S}-\mathrm{O}$ and $\mathrm{S}-\mathrm{OH}$ distances found in sulfoxide and sulfenic acid, respectively. ${ }^{[15]}$ The $S$ atom of the thioether group in $\mathrm{PS} 2 \mathrm{~S}^{\mathrm{Me}}$ remains uncoordinated. The structure adopts a distorted pentagonal-bipyramidal geometry with two $\mathrm{P}$ atoms in the equatorial plane. Seven-coordinate $\mathrm{V}^{\mathrm{IV}}$ complexes are unusual and the only reported example is $\left[\mathrm{V}\left(\mathrm{S}_{2}\right)_{2}\right.$ (terpy)]. ${ }^{[16]}$ Selected bond lengths and angles of 2a and $\mathbf{2 b}$ are listed in Table S1 and Table 2, respectively. The distances of $\mathrm{V}-\mathrm{S}$ bonds occur in a large range (2.374 to $2.551 \AA$ ). The axial V-S distances (2.374 and $2.386 \AA$ ) are comparable to those in $\mathbf{1 b}$ and other reported $\mathrm{V}^{\mathrm{IV}}$-thiolate complexes. ${ }^{[11 \mathrm{a}, 11 \mathrm{~d}-11 \mathrm{~h}]}$ However, the equatorial V-S bond lengths $(2.444,2.434$, and $2.551 \AA$ ) are much longer than those in reported $\mathrm{V}^{\mathrm{IV}}$-thiolate compounds, but are close to those in seven-coordinate vanadium(III)-thiolate complexes. ${ }^{[17]}$

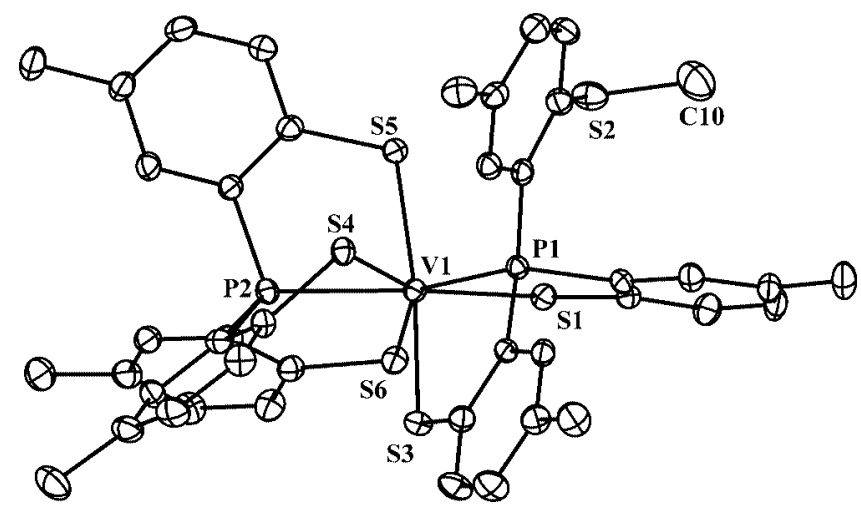

Figure 2. ORTEP diagram of $\mathbf{2 b}$ shown with $35 \%$ thermal ellipsoids. The cation and all hydrogen atoms are omitted for clarity.

\section{Spectroscopic, Electrochemical, and Magnetic Studies}

The patterns of the bands in the UV/Vis spectra of $\mathbf{1 a , b}$ are similar to each other, but are dissimilar to that of $\mathbf{2 a}$, clearly delineating the different coordination sites of $\mathbf{1 a}, \mathbf{b}$ and $\mathbf{2 a}$ in solution state (Figure 3 ). The absorptions of 1a
Table 2. Selected bond lengths [ $[\AA]$ and angles $\left[^{\circ}\right]$ for $\mathbf{2} \mathbf{b} \cdot \mathrm{CH}_{3} \mathrm{OH}$.

\begin{tabular}{lclc}
\hline $\mathrm{V}(1)-\mathrm{S}(1)$ & $2.4435(10)$ & $\mathrm{V}(1)-\mathrm{S}(3)$ & $2.3743(11)$ \\
$\mathrm{V}(1)-\mathrm{S}(4)$ & $2.5513(10)$ & $\mathrm{V}(1)-\mathrm{S}(5)$ & $2.3861(10)$ \\
$\mathrm{V}(1)-\mathrm{S}(6)$ & $2.4336(10)$ & $\mathrm{V}(1)-\mathrm{P}(1)$ & $2.4891(10)$ \\
$\mathrm{V}(1)-\mathrm{P}(2)$ & $2.4305(10)$ & $\mathrm{S}(2)-\mathrm{C}(10)$ & $1.763(5)$ \\
$\mathrm{S}(1)-\mathrm{V}(1)-\mathrm{S}(3)$ & $98.05(4)$ & $\mathrm{S}(4)-\mathrm{V}(1)-\mathrm{P}(1)$ & $70.09(3)$ \\
$\mathrm{S}(1)-\mathrm{V}(1)-\mathrm{S}(5)$ & $92.00(4)$ & $\mathrm{S}(4)-\mathrm{V}(1)-\mathrm{P}(2)$ & $68.22(3)$ \\
$\mathrm{S}(1)-\mathrm{V}(1)-\mathrm{S}(6)$ & $70.05(3)$ & $\mathrm{S}(5)-\mathrm{V}(1)-\mathrm{P}(1)$ & $97.15(4)$ \\
$\mathrm{S}(1)-\mathrm{V}(1)-\mathrm{P}(1)$ & $77.52(3)$ & $\mathrm{S}(5)-\mathrm{V}(1)-\mathrm{S}(3)$ & $168.96(4)$ \\
$\mathrm{S}(1)-\mathrm{V}(1)-\mathrm{P}(2)$ & $144.00(4)$ & $\mathrm{S}(5)-\mathrm{V}(1)-\mathrm{S}(6)$ & $102.52(4)$ \\
$\mathrm{S}(3)-\mathrm{V}(1)-\mathrm{S}(6)$ & $85.30(4)$ & $\mathrm{P}(1)-\mathrm{V}(1)-\mathrm{S}(6)$ & $142.33(4)$ \\
$\mathrm{S}(3)-\mathrm{V}(1)-\mathrm{P}(1)$ & $80.68(3)$ & $\mathrm{P}(2)-\mathrm{V}(1)-\mathrm{S}(3)$ & $93.20(4)$ \\
$\mathrm{S}(4)-\mathrm{V}(1)-\mathrm{S}(1)$ & $146.71(4)$ & $\mathrm{P}(2)-\mathrm{V}(1)-\mathrm{S}(5)$ & $81.18(4)$ \\
$\mathrm{S}(4)-\mathrm{V}(1)-\mathrm{S}(3)$ & $84.40(4)$ & $\mathrm{P}(2)-\mathrm{V}(1)-\mathrm{S}(6)$ & $76.98(3)$ \\
$\mathrm{S}(4)-\mathrm{V}(1)-\mathrm{S}(5)$ & $84.69(3)$ & $\mathrm{P}(2)-\mathrm{V}(1)-\mathrm{P}(1)$ & $138.26(4)$ \\
$\mathrm{S}(4)-\mathrm{V}(1)-\mathrm{S}(6)$ & $142.97(4)$ & & \\
\hline
\end{tabular}

are slightly red-shifted relative to those of $\mathbf{1 b}$ as a result of the methyl substituents of the ligand in 1a. The intense bands appearing in these spectra are very likely caused by the ligand-to-metal charge transfers that mask $\mathrm{d}-\mathrm{d}$ transitions. Cyclic voltammograms (CVs) of complexes $\mathbf{1 a}, \mathbf{b}$ and 2a were measured under nitrogen with ferrocene $(\mathrm{Fc})$ as an external standard. The potentials are referenced versus the $\mathrm{Fc}^{+} / \mathrm{Fc}$ couple as summarized in Table 3 . The CVs of $\mathbf{1 a}$ and 2a display two well-separated reversible waves of equal size as one-electron-reduction and one-electron-oxidation processes (Figure 4). The reduction processes should be interpreted as metal-centered reductions to $\mathrm{V}^{\mathrm{III}}$ species since the thiolate ligands are unlikely to be reduced in this potential range. Although the possibility of ligand-based oxidations should not be excluded, we are inclined to speculate that the oxidation processes are related to metal-centered oxidations since the oxidation of thiolate to thiyl radical is usually irreversible and at higher potential. ${ }^{[12 e, 12 i]}$ The potentials $\left(E_{1 / 2}\right)$ of 1a are much higher than the corresponding potentials of 2a. Presumably, this is related to the six-coordinate metal center in 1a compared with the seven-coordinate metal center in $\mathbf{2 a}$; this is in agreement with lowercoordinate complexes stabilized at lower oxidation states. The differences in potentials of these two complexes are $689 \mathrm{mV}$ for the $\mathrm{V}^{\mathrm{III}} / \mathrm{V}^{\mathrm{IV}}$ couple and $498 \mathrm{mV}$ for the $\mathrm{V}^{\mathrm{IV}} / \mathrm{V}^{\mathrm{V}}$ couple, indicating that the effect of the coordination number on the stabilization of the oxidation state is more pronounced for the former than the latter couple. Indeed, the potentials of redox couples of 1a are closer to those of the corresponding couples in a six-coordinate non-oxo vanadium(IV) complex, $\mathrm{V}^{\mathrm{IV}} \mathrm{L}^{\mathrm{P}}{ }_{2}$, in which $\mathrm{L}^{\mathrm{P}}$ is a tridentate bis(phenolato)phosphane ligand (Table 3). ${ }^{[12 \mathrm{p}]}$ The potentials of $\mathbf{1 a}$ are slightly higher than those in $\mathrm{V}^{\mathrm{IV}} \mathrm{L}^{\mathrm{P}}{ }_{2}$ since the reduced form is more stable in a $\mathrm{P} 2 \mathrm{~S} 4$ environment compared with a P2O4 environment. The cyclic voltammogram of $\mathbf{1 b}$ displays an irreversible reduction wave at $-0.818 \mathrm{~V}$ and an irreversible oxidation wave at $0.149 \mathrm{~V}$, presumably related to the redox processes to $\mathrm{V}^{\mathrm{III}}$ and $\mathrm{V}^{\mathrm{V}}$, respectively. The potentials of $\mathbf{1 b}$ are higher than those of $\mathbf{1 a}$, consistent with the electron-donating nature of the methyl substituent in the ligand of 1a. Some irreversible oxidized waves are observed in the potential range of 0.2 to $0.8 \mathrm{~V}$ for $\mathbf{1 a}, \mathbf{b}$ and 
$\mathbf{2 a}$, and are probably related to the oxidation of thiolate ligand to thiyl radical.

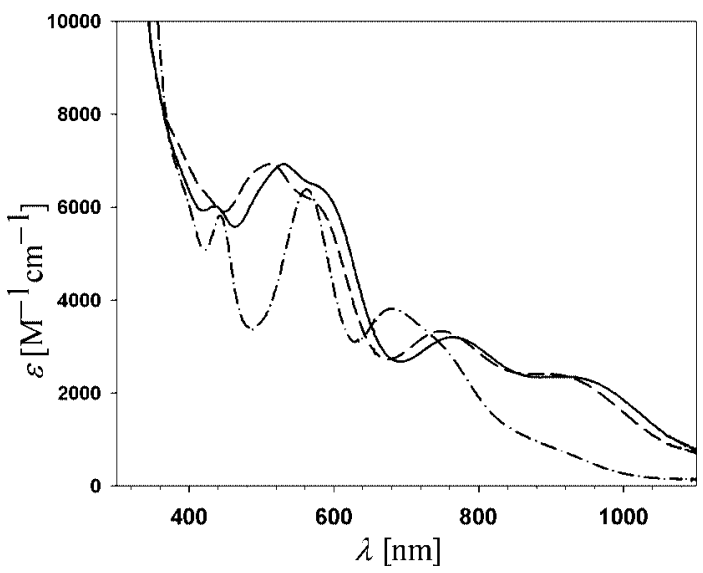

Figure 3. UV/Vis spectra of $\mathbf{1 a}, \mathbf{b}$ and $\mathbf{2 a}$ in $\mathrm{CH}_{2} \mathrm{Cl}_{2}$. Solid line (1a), dashed line (1b), dashed-dotted line (2a).

Table 3. Electrochemical data from cyclic voltammetry. ${ }^{[a]}$

\begin{tabular}{lcccc}
\hline $\begin{array}{l}\text { Com- } \\
\text { plex }\end{array}$ & $E_{1 / 2}{ }^{\text {red }}[\mathrm{V}]^{[\mathrm{b}]}$ & $\Delta E_{\mathrm{p}}{ }^{\text {red }}[\mathrm{mV}]$ & $E_{1 / 2}{ }^{\text {ox }}[\mathrm{V}]^{[\mathrm{b}]}$ & $\Delta E_{\mathrm{p}}{ }^{\text {ox }}[\mathrm{mV}]$ \\
\hline $\mathbf{1 a}$ & -0.872 & 98 & -0.107 & 104 \\
$\mathbf{1 b}$ & $-0.818^{[\mathrm{c}]}$ & - & $0.149^{[\mathrm{c}]}$ & - \\
$\mathbf{2 a}$ & -1.561 & 92 & -0.605 & 86 \\
$\mathrm{~V}^{\mathrm{IV}} \mathrm{L}_{2}{ }_{2}{ }^{[\mathrm{d}]}$ & -1.060 & - & -0.175 & - \\
\hline
\end{tabular}

[a] Measured $0.5 \mathrm{~mm}$ solutions of $\mathbf{1 a}, \mathbf{b}$ and $\mathbf{2 a}$ in $\mathrm{CH}_{2} \mathrm{Cl}_{2}$ with $n \mathrm{Bu}_{4} \mathrm{NBF}_{4}(0.05 \mathrm{M})$, Pt electrode, $\mathrm{Ag} / \mathrm{Ag}\left(\mathrm{NO}_{3}\right)\left(0.01 \mathrm{M}\right.$ in $\left.\mathrm{CH}_{3} \mathrm{CN}\right)$ reference, ambient temperature, scan rate $100 \mathrm{mVs}^{-1}$. [b] Vs. Fc/ $\mathrm{Fc}^{+}$. [c] Irreversible wave, the peak potentials $E_{\mathrm{p}}{ }^{\text {ox }}$ or $E_{\mathrm{p}}{ }^{\text {red }}$ are given. [d] $\mathrm{L}=$ bis(phenolato)phosphane (ref. $\left.{ }^{[12 \mathrm{p}]}\right)$.

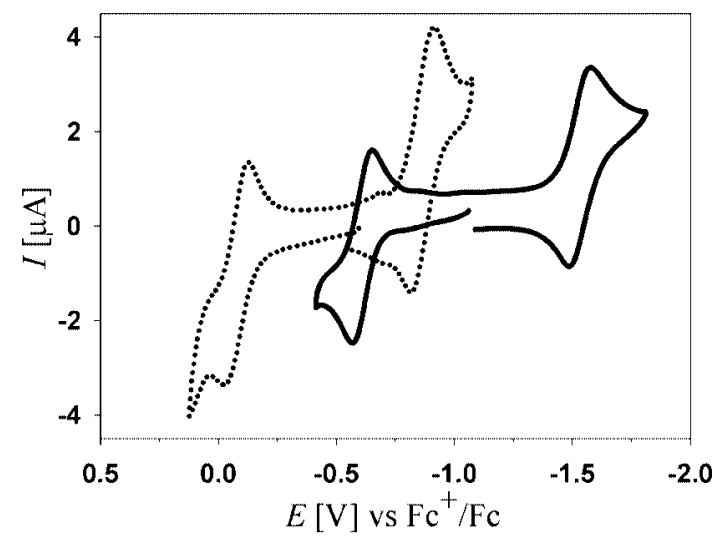

Figure 4. Cyclic voltammograms of complexes 1a (dotted line) and 2a (solid line) in $\mathrm{CH}_{2} \mathrm{Cl}_{2}$ solutions (scan rate: $100 \mathrm{mV} \mathrm{s}^{-1}$ ).

The magnetic properties of the complexes were studied by SQUID measurements over the temperature range 5$300 \mathrm{~K}$. The temperature-independent magnetic moments of 1a and $2 \mathrm{a}$ are $1.78 \pm 0.10$ and $1.68 \pm 0.04 \mu_{\mathrm{B}}$, respectively, close to the spin-only value of one unpaired electron $\left(\mu_{\text {eff }}=\right.$ $\left.1.73 \mu_{\mathrm{B}}\right)$. These results are consistent with a $\mathrm{V}^{\mathrm{IV}}$ ion that has a $S=1 / 2$ ground state. The ${ }^{1} \mathrm{H}$ NMR spectra of $1 \mathbf{a}$ and 2a in $\mathrm{CD}_{2} \mathrm{Cl}_{2}$ exhibit broadened resonance signals in the range of -10 to $20 \mathrm{ppm}$, in agreement with paramagnetic species in the solution state. The EPR spectra of $\mathbf{1 a}, \mathbf{b}$ and 2a in frozen $\mathrm{CH}_{2} \mathrm{Cl}_{2}$ solutions are presented in Figure 5. The spectra of $\mathbf{1 a}, \mathbf{b}$ are not highly resolved, which is probably a result of the bad quality of glass samples. Attempts to obtain better resolved spectra by preparing the samples under various conditions did not succeed. These spectra exhibit an eight-line pattern with hyperfine splitting of $108.01 \cdot 10^{-4}$ and $103.55 \cdot 10^{-4} \mathrm{~cm}^{-1}$ for $\mathbf{1 a}, \mathbf{b}$ and $\mathbf{2 a}$, respectively, centered at $g_{z} \cong 1.97$ that is caused by coupling of the unpaired electron with the ${ }^{51} \mathrm{~V}$ nuclear spin $(I=7 / 2)$. Spin quantification of the EPR signals account for almost $100 \%$ of all three complexes. These results confirm $S=1 / 2$ $\mathrm{d}^{1}$ electronic configuration assignments of the vanadium ions. As shown in Figure 5, each member of the octet is further split into a 1:2:1 triplet of lines, indicating that the electron is coupled to two equivalent ${ }^{31} \mathrm{P}$ nuclei $(I=1 / 2)$ with a superhyperfine splitting of 2.8 and $3.2 \mathrm{mT}$ for $\mathbf{1 a , b}$ and 2a, respectively. The magnetic parameters of the $x$ and $y$ components could not be determined directly from these spectra because of considerable overlapping of lines. We have attempted to simulate these spectra based on $S=1 / 2$ rhombic models with two equivalent coordinating phosphorus nuclei. Notably, we have assumed that the principal axis systems for the $g, A^{\mathrm{V}}$, and $A^{\mathrm{P}}$ tensors are collinear for simplicity, which may not be justified for non-oxo vanadium(IV) complexes as described by Chaudhuri and coworkers. ${ }^{[12 \mathrm{p}]}$ Satisfactory fits are presented in Figure 5 and the derived EPR parameters are presented in Table 4. The EPR parameters of six-coordinate 1a,b exhibit $g_{z}<g_{x, y}<2$ and $A_{z} \gg A_{x}, A_{y}$ characteristic of a $\left(\mathrm{d}_{x y}\right)^{1}$ ground state configuration. ${ }^{[12 \mathrm{e}, 12 \mathrm{p}, 18]}$ The study of complex 2a is the first reported EPR study of a seven-coordinate non-oxo vanadium(IV) complex with approximately $D_{5 h}$ symmetry. For an ideal pentagonal-bipyramidal $\left(D_{5 h}\right)$ symmetry, simple crystal-field considerations place the $\mathrm{e}_{1}{ }^{\prime \prime}\left(\mathrm{d}_{x z}\right.$ and $\left.\mathrm{d}_{y z}\right)$ the lowest. The $\mathrm{a}_{1}{ }^{\prime}\left(\mathrm{d}_{z^{2}}\right)$ and $\mathrm{e}_{2}{ }^{\prime}\left(\mathrm{d}_{x y}, \mathrm{~d}_{x^{2}-y^{2}}\right)$ lie relatively high above $\mathrm{e}_{1}{ }^{\prime \prime}$, and the ordering of $\mathrm{e}_{2}{ }^{\prime}$ and $\mathrm{a}_{1}{ }^{\prime}$ depends on the relative field strength of the equatorial and the axial ligands. The system is subject to Jahn-Teller distortion. Complex 2a adopts a pseudo $D_{5 h}$ pentagonal-bipyramidal geometry with S1, P1, S4, P2, and S6 atoms forming the pentagon. The spin-Hamiltonian parameters (Table 4) are such that $g_{z}<g_{x, y}<2$ and $A_{z}>>A_{x}, A_{y}$. These results are consistent with the unpaired electron being in a nondegenerate $\mathrm{d}_{x z}$ ground state expected for a pentagonal-bipyramidal complex with a $\mathrm{d}^{1}$ electron configuration. The fact that the observed $g$ anisotropy is relatively small suggests a considerable energy difference between the $\mathrm{d}_{x z}$ and $\mathrm{d}_{y z}$ orbitals, even though these orbitals are strongly coupled by spin-orbit interactions.

From the observed spin-Hamiltonian parameters, the Fermi contact term $(k)$ at the ${ }^{51} \mathrm{~V}$ nucleus has been calculated ${ }^{[19]} \mathrm{A}$ large value of $k$ indicates a large contribution to the hyperfine coupling constant by the unpaired electron. The values of the Fermi contact term obtained in the present work $(k=0.53,0.53$, and 0.51 for $\mathbf{1} \mathbf{a}, \mathbf{1} \mathbf{b}$, and $\mathbf{2 a}$, respectively) indicate the moderate hyperfine coupling from the ${ }^{51} \mathrm{~V}$ nucleus. The observed spectral features, the obtained 
Table 4. EPR parameters of $\mathbf{1 a}, \mathbf{b}$ and $\mathbf{2 a}$.

\begin{tabular}{lcccccc}
\hline Compound & $g_{x}$ & $g_{y}$ & $g_{z}$ & $A_{x}\left[10^{-4} \mathrm{~cm}^{-1}\right]$ & $A_{y}\left[10^{-4} \mathrm{~cm}^{-1}\right]$ & $A_{z}\left[10^{-4} \mathrm{~cm}^{-1}\right]$ \\
\hline $\mathbf{1 a}$ & $1.999(9)$ & $1.989(9)$ & $1.976(9)$ & 18.68 & 29.73 & $108.01^{[\mathrm{a}]}$ \\
$\mathbf{1 b}$ & $1.999(2)$ & $1.989(6)$ & $1.976(9)$ & 18.67 & 29.72 & $108.01^{[\mathrm{a}]}$ \\
$\mathbf{2 a}$ & $1.997(9)$ & $1.989(2)$ & $1.979(9)$ & 17.26 & 26.00 & 103.55 \\
\hline
\end{tabular}

[a] The parameter for compounds $\mathbf{1 a}$ and $\mathbf{1 b}$ is only accurate to $\pm 0.9 \cdot 10^{-4} \mathrm{~cm}^{-1}$, because the spectra of $\mathbf{1 a}$ and $\mathbf{1 b}$ are not as well-resolved as $\mathbf{2 a}$ in the high-field region.

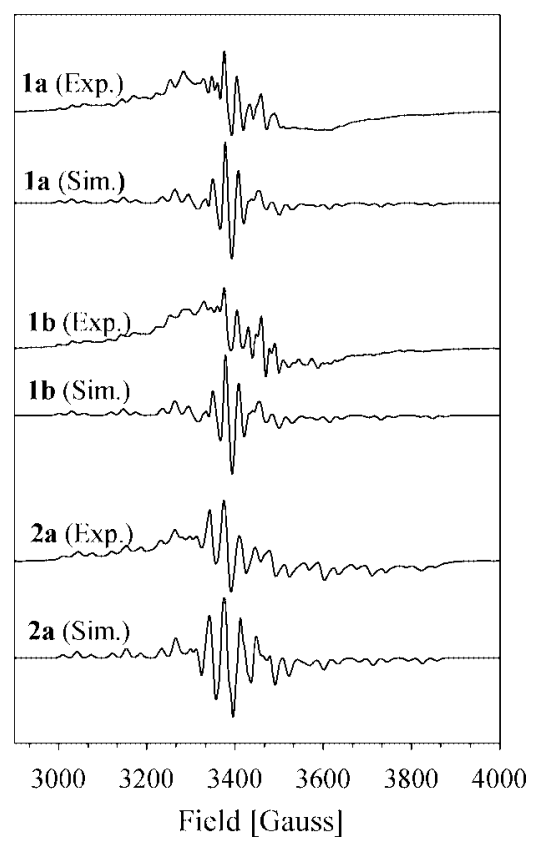

Figure 5. Experimental and simulated EPR spectra of 1a,b and $\mathbf{2 a}$. Instrument settings: microwave frequency, $9.5192 \mathrm{GHz}$ for $\mathbf{1 a}$, 9.5158 GHz for $\mathbf{1 b}, 9.5152 \mathrm{GHz}$ for $\mathbf{2 a}$; modulation amplitude, $8 \mathrm{G}$ at $100 \mathrm{kHz}$; temperature, $5 \mathrm{~K}$; microwave power, $5 \mathrm{~mW}$.

spin-Hamiltonian parameters with low $k$ values, and the isotropic superhyperfine coupling from the two equivalent phosphorus nuclei signify the delocalization of the unpaired electron density away from the $\mathrm{V}^{\mathrm{IV}}$ metal center.

\section{The Disulfide Formation and the Alkylation of Coordinated Thiolate}

Ligand-based reactions of metal-thiolate complexes are well-known. ${ }^{[11 \mathrm{~b}, 15 \mathrm{a}, 20]}$ The reactions include alkylation, metalation, and oxygenation of bound sulfur centers. The formation of disulfide along with the reduction of metal ions has also been seen in metal-thiolate chemistry. ${ }^{[11 \mathrm{e}, 11 \mathrm{~g}, 13,21]}$ However, it has never been reported that $\mathrm{V}^{\mathrm{V}}$ species mediate the disulfide formation and the alkylation of thiolate, as presented in this work. The mechanism of forming the thioether group contained in $\mathbf{2} \mathbf{a}, \mathbf{b}$ is less clear. The alkylation of coordinated thiolate groups is mostly limited to late-transition-metal complexes such as $\mathrm{Ni}^{\mathrm{II}}, \mathrm{Ru}^{\mathrm{II}}, \mathrm{Fe}^{\mathrm{II}}$, and $\mathrm{Zn}^{\mathrm{II}}$ thiolates, where bound sulfur atoms tend to react with electrophiles like carbonium sources. ${ }^{[20 \mathrm{a}, 20 \mathrm{~d}, 20 \mathrm{~g}, 22]}$ The nucleophilicity of bound sulfur atoms has been attributed to a four-electron repulsion between a sulfur lone pair and electrons in filled metal d-orbitals. However, in the case of high- valent vanadium thiolates, the electron repulsion stemming from the metal-sulfur $\mathrm{d} \pi-\mathrm{p} \pi$ interactions is undermined by the electron deficiency of the metal center. Thus, an electrophilic attack of bound sulfur to carbon in methoxide leading to the formation of $\mathbf{2 a , \mathbf { b }}$ is less likely, but cannot be excluded. More likely, the methylation of thiolate might involve the homolytic cleavage of the $\mathrm{C}-\mathrm{O}$ bond in methoxide by a bound thiyl radical generated by the reaction of $\mathrm{V}^{\mathrm{V}}$ with thiolate. ${ }^{[23]}$ In this case, the initial step possibly involved the reduction of $\mathrm{V}^{\mathrm{V}}$ to $\mathrm{V}^{\mathrm{IV}}$ and the oxidation of thiolate to thiyl radical. ${ }^{[24]}$ Thus, a $\mathrm{V}^{\mathrm{IV}}(\mathrm{RS} \cdot)\left(\mathrm{OCH}_{3}\right)$ species might be proposed as an intermediate.

\section{Conclusions}

This work describes the redox chemistry that occurs in the reactions of vanadium(v) with thiolate groups, leading to the formation of two types of non-oxo vanadium(IV) complexes: one with disulfide- and the other with thioethercontaining ligands, as shown by $\mathbf{1} \mathbf{a}, \mathbf{b}$ and $\mathbf{2 a}, \mathbf{b}$, respectively. The chemistry here contrasts with the reported reactions of $\mathrm{VO}^{3+}$ with thiolate-containing ligands, NS3 and btap ${ }^{3-}$ $\left\{\mathrm{NS} 3=\left[\mathrm{N}\left(\mathrm{CH}_{2} \mathrm{CH}_{2} \mathrm{~S}\right)_{3}\right]^{3-}\right.$, btap $^{3-}=2$-[bis(ethylthiolato $)-$ amino]-4-methylphenolate\}, in which redox chemistry was not involved and oxovanadium(v) complexes binding with the title ligands were obtained. ${ }^{[11 b, 11 d]}$ Compared with NS3 and btap $^{3-}$ ligands, the PS3 system might be attributed to a better driving force of the redox process between $\mathrm{V}^{\mathrm{V}} / \mathrm{V}^{\mathrm{IV}}$ and $\mathrm{RS}^{-} / \mathrm{RS} \cdot$ couples, consequently generating a $\mathrm{V}^{\mathrm{IV}}-\mathrm{RS}$. intermediate that might be a key species for forming $\mathbf{1 a}, \mathbf{b}$ and $\mathbf{2 a}, \mathbf{b}$.

\section{Experimental Section}

General Considerations: Manipulations were performed under nitrogen by standard Schlenk techniques or in a nitrogen-filled glove box. $\left[\mathrm{P}\left(\mathrm{C}_{6} \mathrm{H}_{4}-2-\mathrm{SH}\right)_{3}\right],\left[\mathrm{P}\left(\mathrm{C}_{6} \mathrm{H}_{3}-5-\mathrm{Me}-2-\mathrm{SH}\right)_{3}\right],{ }^{[25]}$ and $\mathrm{VO}(i \mathrm{PrO})_{3}{ }^{[26]}$ were synthesized according to literature procedures. Solvents were dried, distilled, and degassed using standard techniques. All other starting materials were obtained commercially and used without further purification.

Physical Methods: Electronic spectra were recorded in the range of $300-1100 \mathrm{~nm}$ on a Hewlett Packard 8453 spectrophotometer. Electrochemical studies were performed at ambient temp. under nitrogen with a CHI 600A electrochemical analyzer. Cyclic voltammograms were obtained by using a three-component system consisting of a platinum-disk working electrode, a platinum-wire auxiliary electrode, and a $\mathrm{Ag} / \mathrm{Ag}\left(\mathrm{NO}_{3}\right)\left(0.01 \mathrm{M}\right.$ in $\left.\mathrm{CH}_{3} \mathrm{CN}\right)$ reference electrode. The experiments were performed in $\mathrm{CH}_{2} \mathrm{Cl}_{2}$ by using tetrabutylammonium tetrafluoroborate $(0.05 \mathrm{M})$ as the supporting 
electrolyte. The ferrocenium/ferrocene $\left(\mathrm{Fc}^{+} / \mathrm{Fc}\right)$ couple was measured as an external standard. Under our experimental conditions, the $\mathrm{Fc}^{+} / \mathrm{Fc}$ couple was at $E_{1 / 2}\left(\Delta E_{\mathrm{p}}\right)=0.161 \pm 0.01 \mathrm{~V}(130 \mathrm{mV})$ vs. $\mathrm{Ag} / \mathrm{Ag}\left(\mathrm{NO}_{3}\right)\left(0.01 \mathrm{M}\right.$ in $\left.\mathrm{CH}_{3} \mathrm{CN}\right)$. The ${ }^{1} \mathrm{H}$ NMR spectra were recorded with a BRUKER AMX-400 at ambient temp. EPR spectra were obtained at X-band using a Bruker EMX spectrometer equipped with a Bruker TE102 cavity and an Advanced Research System continuous-flow cryostat $(3.2-200 \mathrm{~K})$. The microwave frequency was measured with a Hewlett-Packard 5246L electronic counter. The instrument settings are shown in the Figure caption. SQUID magnetic measurements were performed with a QUANTUM DESIGN MPMS-7 with a field of $5000 \mathrm{G}$. The measurements were taken over the following temp. ranges with the indicated increments: $5-10 \mathrm{~K}$ (one data point every $1 \mathrm{~K}$ ), 12-20 K (one data point every $2 \mathrm{~K}$ ), $23-50 \mathrm{~K}$ (one data point every $3 \mathrm{~K}$ ), $55-100 \mathrm{~K}$ (one data point every $5 \mathrm{~K}$ ), $110-300 \mathrm{~K}$ (one data point every $10 \mathrm{~K}$ ). Diamagnetic contributions were estimated for each compound by using Pascal's constants.

Synthesis of $\left[\mathbf{V}^{\mathbf{I V}}\left(\mathbf{P 2 S 4}^{\prime}\right)\right]$ (1a): An $i \mathrm{PrOH}$ solution of $\mathrm{VO}(i \mathrm{PrO})_{3}$ $(0.061 \mathrm{~g}, 0.25 \mathrm{mmol})$ was added to an ether solution of $\left[\mathrm{PS}^{\prime}\right] \mathrm{H}_{3}$ $(0.100 \mathrm{~g}, 0.25 \mathrm{mmol})$ to generate a bluish-purple solution. After stirring for $1 \mathrm{~h}$, a bluish-purple solid precipitated. The solid was filtered in the air and was followed by recrystallization from $\mathrm{CH}_{2} \mathrm{Cl}_{2}$ and hexane in anaerobic conditions to yield the crystalline form of $1 \mathrm{a}\left[0.040 \mathrm{~g}, 0.047 \mathrm{mmol}\right.$, ca. $19 \%$ based on $\left.\mathrm{VO}(i \mathrm{PrO})_{3}\right]$. $\mathrm{C}_{42} \mathrm{H}_{36} \mathrm{P}_{2} \mathrm{~S}_{6} \mathrm{~V}$ (846.01): calcd. C 59.63, H 4.29, S 22.74; found $\mathrm{C}$ 59.42, $\mathrm{H} 4.28, \mathrm{~S}$ 22.53. UV/Vis in $\mathrm{CH}_{2} \mathrm{Cl}_{2}\left(\lambda, \mathrm{nm} ; \varepsilon, \mathrm{M}^{-1} \mathrm{~cm}^{-1}\right): 438$ $\left(6.02 \cdot 10^{3}\right), 531\left(6.92 \cdot 10^{3}\right), 764\left(3.21 \cdot 10^{3}\right), 918\left(2.40 \cdot 10^{3}\right)$.

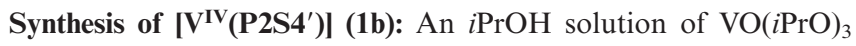
$(0.068 \mathrm{~g}, 0.28 \mathrm{mmol})$ was added to an ether solution of $[\mathrm{PS} 3] \mathrm{H}_{3}$ $(0.100 \mathrm{~g}, 0.28 \mathrm{mmol})$ to generate a bluish-purple solution. After stirring for $1 \mathrm{~h}$, a bluish-purple solid precipitated. The solid was filtered in the air and was followed by recrystallization from benzene and ether in anaerobic conditions to yield the crystalline form of $1 \mathbf{b}\left[0.017 \mathrm{~g}, 0.023 \mathrm{mmol}\right.$, ca. $8.2 \%$ based on $\left.\mathrm{VO}(i \mathrm{PrO})_{3}\right]$. $\mathrm{C}_{36} \mathrm{H}_{24} \mathrm{P}_{2} \mathrm{~S}_{6} \mathrm{~V}$ (761.85): calcd. C 56.75, H 3.18, S 25.25; found $\mathrm{C}$ 56.21, H 3.17, S 24.40. UV/Vis in $\mathrm{CH}_{2} \mathrm{Cl}_{2}\left(\lambda, \mathrm{nm} ; \varepsilon, \mathrm{M}^{-1} \mathrm{~cm}^{-1}\right): 513$ $\left(6.93 \cdot 10^{3}\right), 747\left(3.33 \cdot 10^{3}\right), 890\left(2.41 \cdot 10^{3}\right)$.

Synthesis of $\left[\mathrm{V}^{\mathrm{IV}}\left(\mathrm{PS3}^{\prime}\right)\left(\mathrm{PS}^{\mathrm{Me}} \mathrm{Se}^{\mathrm{Me}}\right)\right]\left[\mathrm{N}\left(\mathrm{C}_{2} \mathrm{H}_{5}\right)_{4}\right](\mathbf{2 a})$ and $\left[\mathrm{V}^{\mathrm{IV}}\left(\mathrm{PS}^{\prime}\right)\right.$ $\left.\left(\mathbf{P S}^{2} \mathbf{S e}^{\mathrm{Me}}\right)\right]\left[\mathbf{N}\left(\mathrm{C}_{2} \mathbf{H}_{5}\right)_{3}\left(\mathbf{C H}_{2} \mathbf{P h}\right)\right] \mathbf{( 2 b )}$ : An $i \mathrm{PrOH}$ solution of VO$(i \mathrm{PrO})_{3}(0.060 \mathrm{~g}, 0.25 \mathrm{mmol})$ was added to a methanol solution of [PS3'] $\mathrm{H}_{3}(0.100 \mathrm{~g}, 0.25 \mathrm{mmol})$ and $\mathrm{CH}_{3} \mathrm{ONa}(0.040 \mathrm{~g}, 0.75 \mathrm{mmol})$ to generate a brown solution. The reaction mixture changed to a purple color after stirring for $30 \mathrm{~min}$. After filtering through Celite, the solution was concentrated and layered with $\left(\mathrm{C}_{2} \mathrm{H}_{5}\right)_{4} \mathrm{NBr}$ $(0.050 \mathrm{~g}, 0.24 \mathrm{mmol})$ in methanol to give a purple crystalline solid of $2 \mathrm{a}\left[0.020 \mathrm{~g}, 0.02 \mathrm{mmol}\right.$, ca. $8 \%$ based on $\left.\mathrm{VO}(i \mathrm{PrO})_{3}\right]$. $\mathrm{C}_{51} \mathrm{H}_{59} \mathrm{NP}_{2} \mathrm{~S}_{6} \mathrm{~V}$ (991.23): calcd. C 61.79, H 6.00, N 1.41, S 19.41; found $\mathrm{C} 60.99, \mathrm{H} 6.19, \mathrm{~N} 1.33, \mathrm{~S}$ 18.73. UV/Vis in $\mathrm{CH}_{2} \mathrm{Cl}_{2}(\lambda$, $\left.\mathrm{nm} ; \varepsilon, \mathrm{M}^{-1} \mathrm{~cm}^{-1}\right)$ : $443\left(4.53 \cdot 10^{3}\right), 562\left(4.92 \cdot 10^{3}\right), 677\left(2.98 \cdot 10^{3}\right)$. The procedure for the synthesis of $\mathbf{2} \mathbf{b}$ is the same except $\left(\mathrm{C}_{2} \mathrm{H}_{5}\right)_{3}$ $\left(\mathrm{CH}_{2} \mathrm{Ph}\right) \mathrm{NBr}$ was used for the cation. $2 \mathbf{b}, \mathrm{C}_{56} \mathrm{H}_{61} \mathrm{NP}_{2} \mathrm{~S}_{6} \mathrm{~V}$ (1053.38): calcd. C 63.85, H 5.85, N 1.33, S 18.27; found C 62.99, H 6.05, N 1.32, S 17.82 .

\section{Crystallographic Structure Determination}

Each crystal was mounted on a glass fiber and quickly coated in epoxy resin. Diffraction measurements were carried out at 295(2) K for $\mathbf{1 b}$ and $150(2) \mathrm{K}$ for $\mathbf{2 b}$ with a Bruker SMART $1000 \mathrm{CCD}$ diffractometer with graphite-monochromated Mo-Ka radiation $(\lambda=$ $0.7107 \AA$ ). Least-squares refinement of the positional and anisotropic thermal parameters for the contribution of all non-hydrogen atoms and fixed hydrogen atoms was based on $F^{2}$. A SADABS absorption correction was made. ${ }^{[27]}$ The SHELXTL structural refinement program was employed. ${ }^{[28]}$ All non-hydrogen atoms were refined with anisotropic displacement factors. All hydrogen atoms were calculated using the riding model. Detailed data and refinement parameters are summarized in Table 5 (1) and $\mathbf{2 b}$ ) and Table S2 (2a).

Table 5. Crystallographic data for compounds $\mathbf{1 b}$ and $\mathbf{2 b}$.

\begin{tabular}{lll}
\hline & $\mathbf{1 b} \cdot 2 \mathrm{C}_{6} \mathrm{H}_{6}$ & $\mathbf{2 b} \cdot \mathrm{CH}_{3} \mathrm{OH}$ \\
\hline Formula & $\mathrm{C}_{48} \mathrm{H}_{36} \mathrm{P}_{2} \mathrm{~S}_{6} \mathrm{~V}$ & $\mathrm{C}_{57} \mathrm{H}_{65} \mathrm{NOP}_{2} \mathrm{~S}_{6} \mathrm{~V}$ \\
$M\left[\mathrm{~g} \mathrm{~mol}{ }^{-1}\right]$ & 918.01 & 1085.34 \\
$T[\mathrm{~K}]$ & $295(2)$ & $150(2)$ \\
Crystal system & Monoclinic & Monoclinic \\
Space group & $P 2_{1} / a$ & $P 2_{1} / n$ \\
$a[\AA]$ & $18.0270(10)$ & $12.58000(10)$ \\
$b[\AA]$ & $13.8510(9)$ & $33.6470(3)$ \\
$c[\AA]$ & $19.1040(11)$ & $14.25500(10)$ \\
$a\left[^{\circ}\right]$ & 90 & 90 \\
$\beta\left[^{\circ}\right]$ & $114.260(3)$ & 113.58 \\
$\gamma\left[^{\circ}\right]$ & 90 & 90 \\
$V\left[^{3} \AA^{3}\right]$ & $4348.9(4)$ & $5529.99(8)$ \\
$Z$ & 4 & 4 \\
$D_{\text {calcd. }}\left[\mathrm{gcm}^{-1}\right]$ & 1.402 & 1.304 \\
$\mu\left(\mathrm{Mo}-K_{\alpha}\right)\left[\mathrm{mm}^{-1}\right]$ & 0.624 & 0.503 \\
$F(000)$ & 1892 & 2284 \\
Collected data & 23029 & 33541 \\
$\mathrm{Unique}^{\circ}$ data $\left(R_{\text {int }}\right)$ & $7636(0.2093)$ & $9649(0.0535)$ \\
Refined parameters & 515 & 613 \\
$R_{1}{ }^{\text {[a] }}[I>2 \sigma(I)]$ & 0.0753 & 0.0525 \\
$w R_{2}{ }^{[\mathrm{b}]}[I>2 \sigma(I)]$ & 0.1270 & 0.1433 \\
$\mathrm{GOF}^{[\mathrm{cc}]}$ & 1.226 & 1.019
\end{tabular}

[a] $R_{1}=\Sigma|| F_{\mathrm{o}}|-| F_{\mathrm{c}}\left|/ \Sigma \| F_{\mathrm{o}}\right| \cdot[\mathrm{b}] w R_{2}=\left\{\Sigma\left[w\left(F_{\mathrm{o}}{ }^{2}-F_{\mathrm{c}}{ }^{2}\right)^{2}\right] / \Sigma\left[w\left(F_{\mathrm{o}}{ }^{2}\right)^{2}\right]\right\}^{1 / 2}$. [c] Goodness-of-fit on $F^{2}$.

CCDC-272405 (for 1b), CCDC-287713 (for 2a), and CCDC272406 (for 2b) contain the supplementary crystallographic data for this paper. These data can be obtained free of charge from The Cambridge Crystallographic Data Centre via www.ccdc.cam.ac.uk/ data_request/cif.

Supporting Information (see footnote on the first page of this article): ORTEP diagram of 2a (Figure S1), selected bond lengths and angles for 2a (Table S1), and crystallographic data of 2a (Table S2).

\section{Acknowledgments}

We thank the National Science Council in Taiwan (NSC, 93-2113M-006-012-) for generous support of this work. Helpful discussions with Professor I-Wen Sun at National Cheng Kung University are gratefully acknowledged.

[1] a) D. C. Crans, J. J. Smee, E. Gaidamauskas, L. Yang, Chem. Rev. 2004, 104, 849-902; b) E. J. Baran, J. Braz. Chem. Soc. 2003, 14, 878-888; c) E. J. Baran, Coord. Chem. Rev. 2003, 237, 1-286. (A special issue: "New Directions in Chemistry and Biological Chemistry of Vanadium"); d) E. J. Baran, J. Inorg. Biochem. 2000, 80, 1-194. (A special issue dedicated to biological aspects of vanadium).

[2] E. J. Baran, J. Inorg. Biochem. 2000, 80, 1-10.

[3] a) G. Huyer, S. Liu, J. Kelly, J. Moffat, P. Payette, B. Kennedy, G. Tsaprailis, M. J. Gresser, C. Ramachandran, J. Biol. Chem. 1997, 272, 843-851; b) J. E. Benabe, L. A. Echegoyen, B. Pastrana, M. Martínez-Maldonado, J. Biol. Chem. 1987, 262, 9555-9560; c) D. Rehder, Inorg. Chem. Commun. 2003, 6, 604 617. 
[4] S. W. Taylor, B. Kammerer, E. Bayer, Chem. Rev. 1997, 97, $333-$ 346.

[5] H. Michibata, N. Yamaguchi, T. Uyama, T. Ueki, Coord. Chem. Rev. 2003, 237, 41-51.

[6] C. D. Garner, E. M. Armstrong, R. E. Berry, R. L. Beddoes, D. Collison, J. J. A. Cooney, S. N. Ertok, M. Helliwell, J. Inorg. Biochem. 2000, 80, 17-20.

[7] R. E. Berry, E. M. Armstrong, R. L. Beddoes, D. Collison, S. N. Ertok, M. Helliwell, C. D. Garner, Angew. Chem. Int. Ed. 1999, 38, 795-797.

[8] M. F. C. Guedes da Silva, J. A. L. Silva, J. J. R. Fraústo da Silva, A. J. L. Pombeiro, C. Amatore, J.-N. Verpeaux, J. Am. Chem. Soc. 1996, 118, 7568-7573.

[9] M. Bruech, M. E. Quintanilla, W. Legrum, J. Koch, K. J. Netter, G. F. Fuhrmann, Toxicology 1984, 31, 283-295.

[10] a) H. Sakurai, H. Sano, T. Takino, H. Yasui, J. Inorg. Biochem. 2000, 80, 99-105; b) H. Sakurai, H. Watanabe, H. Tamura, H. Yasui, R. Matsushita, J. Takada, Inorg. Chim. Acta 1998, 283, 175-183; c) D. Rehder, J. C. Pessoa, C. F. Geraldes, M. M. Castro, T. Kabanos, T. Kiss, B. Meier, G. Micera, L. Pettersson, M. Rangel, A. Salifoglou, I. Turel, D. Wang, J. Biol. Inorg. Chem. 2002, 7, 384-396.

[11] a) J. J. A. Cooney, M. D. Carducci, A. E. McElhaney, H. D. Selby, J. H. Enemark, Inorg. Chem. 2002, 41, 7086; b) C. R. Cornman, T. C. Stauffer, P. D. Boyle, J. Am. Chem. Soc. 1997, 119, 5986-5987; c) J. K. Money, J. R. Nicholson, J. C. Huffman, G. Christou, Inorg. Chem. 1986, 25, 4072-4074; d) K. K. Nanda, E. Sinn, A. W. Addison, Inorg. Chem. 1996, 35, 1-2; e) W. Tsagkalidis, D. Rodewald, D. Rehder, Inorg. Chem. 1995, 34, 1943-1945; f) D. Wang, M. Ebel, C. Schulzke, C. Grüning, S. K. S. Hazari, D. Rehder, Eur. J. Inorg. Chem. 2001, 935-942; g) D. Wang, A. Behrens, M. Farahbakhsh, J. Gätjens, D. Rehder, Chem. Eur. J. 2003, 9, 1805-1813; h) W. Tsagkalidis, D. Rehder, J. Biol. Inorg. Chem. 1996, 1, 507-514; i) H. Nekola, D. Wang, C. Grüning, J. Gätjens, A. Behrens, D. Rehder, Inorg. Chem. 2002, 41, 2379-2384.

[12] a) M. Farahbakhsh, H. Schmidt, D. Rehder, Chem. Commun. 1998, 2009-2010; b) V. Vergopoulos, S. Jantzen, D. Rodewald, D. Rehder, J. Chem. Soc., Chem. Commun. 1995, 377-378; c) T. A. Kabanos, A. J. P. White, D. J. Williams, J. D. Woollins, J. Chem. Soc., Chem. Commun. 1992, 17-18; d) S. Bruni, A. Caneschi, F. Cariati, C. Delfs, A. Dei, D. Gatteschi, J. Am. Chem. Soc. 1994, 116, 1388-1394; e) P. R. Klich, A. T. Daniher, P. R. Challen, Inorg. Chem. 1996, 35, 347-356; f) S. R. Cooper, Y. B. Koh, K. N. Raymond, J. Am. Chem. Soc. 1982, 104, 5092-5102; g) M. A. A. F. de C. T. Carrondo, M. T. L. S. Duarte, J. C. Pessoa, J. A. L. Silva, J. J. R. Fraústo da Silva, M. C. T. A. Vaz, L. F. Vilas-Boas, J. Chem. Soc., Chem. Commun. 1988, 1158-1159; h) U. Auerbach, B. S. P. C. D. Vedova, K. Wieghardt, B. Nuber, J. Weiss, J. Chem. Soc., Chem. Commun. 1990, 1004-1005; i) T. Beissel, T. Glaser, F. Kesting, K. Wieghardt, B. Nuber, Inorg. Chem. 1996, 35, 3936-3947; j) P. Comba, L. M. Engelhardt, J. M. Harrowfield, G. A. Lawrance, L. L. Martin, A. M. Sargeson, A. H. White, J. Chem. Soc., Chem. Commun. 1985, 174-176; k) A. Neves, A. S. Ceccato, I. Vencato, Y. P. Mascarenhas, C. Erasmus-Buhr, J. Chem. Soc., Chem. Commun. 1992, 652-654; 1) T. A. Kabanos, A. M. Z. Slawin, D. J. Williams, J. D. Woolins, J. Chem. Soc., Dalton Trans. 1992, 1423-1427; m) A. A. Diamantis, M. R. Snow, J. A.
Vanzo, J. Chem. Soc., Chem. Commun. 1976, 264-265; n) B. Kang, L. Weng, H. Liu, D. Wu, L. Huang, C. Lu, J. Cai, X. Chen, J. Lu, Inorg. Chem. 1990, 29, 4873-4877; o) T. A. Kabanos, A. M. Z. Slawin, D. J. Williams, J. D. Woollins, J. Chem. Soc., Chem. Commun. 1990, 193-194; p) T. K. Paine, T. Weyhermüller, L. D. Slep, F. Neese, E. Bill, E. Bothe, K. Wieghardt, P. Chaudhuri, Inorg. Chem. 2004, 43, 7324-7338; q) P. D. Smith, R. E. Berry, S. M. Harben, R. L. Beddoes, M. Helliwell, D. Collison, C. D. Garner, J. Chem. Soc., Dalton Trans. 1997, 4509-4516.

[13] J. R. Dilworth, Y. Zheng, J. R. Miller, J. Chem. Soc., Dalton Trans. 1992, 1757-1758.

[14] R. H. Laitinen, H. Riihimäki, M. Haukka, S. Jääskeläinen, T. A. Pakkanen, J. Pursiainen, Eur. J. Inorg. Chem. 1999, 12531258.

[15] a) For instance: $\mathrm{S}=\mathrm{O}$ distances in sulfoxide-containing complexes are 1.5-1.6 ̊. C. A. Grapperhaus, M. Y. Darensbourg, Acc. Chem. Res. 1998, 31, 451-459; b) For instance: S-OH distance in a sulfenic acid is $1.679 \AA$. K. Goto, M. Holler, R. Okazaki, J. Am. Chem. Soc. 1997, 119, 1460-1461.

[16] F. T. Al-Ani, D. L. Hughes, C. J. Pickett, J. Chem. Soc., Dalton Trans. 1988, 1705-1707.

[17] H.-F. Hsu, W.-C. Chu, C.-H. Hung, J.-H. Liao, Inorg. Chem. 2003, 42, 7369-7371.

[18] A. Jezierski, J. B. Raynor, J. Chem. Soc., Dalton Trans. 1981, $1-7$.

[19] D. Kivelson, S.-K. Lee, J. Chem. Phys. 1964, 41, 1896-1902.

[20] a) C. A. Grapperhaus, S. Poturovic, M. Mashuta, Inorg. Chem. 2002, 41, 4309-4311; b) M. Kumar, R. O. Day, G. J. Colpas, M. J. Maroney, J. Am. Chem. Soc. 1989, 111, 5974-5976; c) E. L. Blinn, D. H. Busch, J. Am. Chem. Soc. 1968, 90, 4280 4285; d) J. J. Wilker, S. J. Lippard, Inorg. Chem. 1997, 36, 969 978; e) L. F. Lindoy, D. H. Busch, Inorg. Chem. 1974, 13, 2494 2498; f) R. M. Buonomo, I. Font, M. J. Maguire, J. H. Reibenspies, T. Tuntulani, M. Y. Darensbourg, J. Am. Chem. Soc. 1995, 117, 963; g) G. Musie, J. H. Reibenspies, M. Y. Darensbourg, Inorg. Chem. 1998, 37, 302-310; h) Y.-M. Hsiao, S. S. Chojnacki, P. Hinton, J. H. Reibenspies, M. Y. Darensbourg, Organometallics 1993, 12, 870-875.

[21] B. Albela, E. Bothe, O. Brosch, K. Mochizuki, T. Weyhermüller, K. Wieghardt, Inorg. Chem. 1999, 38, 51315138.

[22] M. T. Ashby, J. H. Enemark, D. L. Lichtenberger, Inorg. Chem. 1988, 27, 191-197.

[23] Attempts to isolate the reaction intermediates or other products were unsuccessful.

[24] X. Shi, X. Sun, N. S. Dalal, FEBS LETT. 1990, 271, 185-188.

[25] E. Block, G. Ofori-Okai, J. Zubieta, J. Am. Chem. Soc. 1989, 111, 2327-2329.

[26] H. Hillerns, D. Rehder, Chem. Ber. 1991, 124, 2249-2254.

[27] G. M. Sheldrick, SADABS, Siemens Area Detector Absorption Correction Program, University of Göttingen, Göttingen, Germany, 1996.

[28] G. M. Sheldrick, SHELXTL, Program for Crystal Structure Determination, Siemens Analytical X-ray Instruments Inc., Madison, WI, 1994.

Received: September 29, 2005 Published Online: January 26, 2006 